\title{
Celiac disease screening in Brazilian patients with osteoporosis
}

\author{
Pesquisa de doença celíaca em pacientes \\ brasileiros com osteoporose
}

Luiza Gusso', Mariana Cionek Simões', Thelma L. Skare', Renato Nisihara' ${ }^{2}$, Claudine C. Burkiewicz', Shirley Utiyama ${ }^{3}$

${ }^{1}$ Rheumatology Unit, Hospital Universitário Evangélico de Curitiba (HUEC), Curitiba, PR, Brazil

2 Universidade Positivo, Curitiba, PR, Brazil

${ }^{3}$ Immunopathology Laboratory, Clinical Hospital, Universidade Federal do Paraná (UFPR), Curitiba PR, Brazil
Correspondence to:

Thelma L. Skare

Centro Médico

Hospital Universitário Evangélico

de Curitiba

Rua Sete de Setembro, 4713

80240000 - Curitiba, PR, Brazil

tskare@onda.com.br

Received on Aug/5/2013

Accepted on Dec/10/2013

\begin{abstract}
Objective: To analyze if it is worthwhile to screen Brazilian osteoporotic patients for celiac disease (CD). Subjects and methods: One hundred patients with osteoporosis and 97 controls were evaluated for $\lg \mathrm{A}-\mathrm{EmA}$ ( $\lg \mathrm{A}$ anti-endomysial antibodies) by indirect immunofluorescence method and IgG-anti-tTG (tissue transglutaminase) by ELISA assay. Positive patients were invited to have gastrointestinal endoscopy with jejunal biopsy. Results: Two patients had positive $\lg$-anti-tTG test and one of them also showed positive $\operatorname{lgA}$-EmA. Only the latter had a positive duodenal biopsy for $\mathrm{CD}$. None of the controls were positive for either auto-antibodies. Conclusion: We observed low prevalence of CD in osteoporotic Brazilian patients. This finding does not support routine screening for $\mathrm{CD}$ in patients with osteoporosis in our geographic region. Arq Bras Endocrinol Metab. 2014;58(3):270-3
\end{abstract}

\section{Keywords}

Osteoporosis; celiac disease; auto-antibodies; gluten

\section{RESUMO}

Objetivo: Analisar a necessidade de investigar doença celíaca (DC) em pacientes brasileiros com osteoporose. Sujeitos e métodos: No total, cem pacientes com osteoporose e 97 controles foram pesquisados $\lg \mathrm{A}-\mathrm{EmA}$ ( $\lg \mathrm{A}$ antiendomísio) pelo método de imunofluorescência indireta e IgG-anti-tTG (transglutaminase tecidual) pelo teste de ELISA. Os pacientes positivos foram convidados a realizar endoscopia gastrointestinal com biópsia jejunal. Resultados: Duas pacientes foram positivas para o teste lgG-anti-tTG. Destas, somente uma também foi positiva para $\lg \mathrm{A}-\mathrm{EmA}$. Esta última possuía achados de biópsia jejunal sugestivos de DC. Nenhum dos controles foi positivo para nenhum dos anticorpos. Conclusão: Foi observada baixa prevalência de DC nos pacientes brasileiros com osteoporose. Esse achado não oferece suporte para pesquisa rotineira de DC em pacientes com osteoporose em nossa região geográfica. Arq Bras Endocrinol Metab. 2014;58(3):270-3

\section{Descritores}

Osteoporose; doença celíaca; autoanticorpos; glúten

\section{INTRODUCTION}

$\mathrm{O}$ steoporosis (OP) is a systemic skeletal disease characterized by low bone mass and microarchitectural deterioration with consequent increase in bone fragility and susceptibility to fracture. It is a multifactorial disorder influenced by genetic $(70 \%)$ and environmental factors $(30 \%)(1)$. With the recent increase in life expectancy, OP has become a public health problem with considerable economic and social importance (2). The Brazilian Osteoporosis Study (3), published in 2009, identified clinical risk factors associated with fragility fractures and OP in the Brazilian population. Clinical risk factors related to osteoporosis in Brazilian women were advanced age, early menopause, sedentarism, poorer quality of life, higher dietary phosphorus intake, diabetes, recurrent falls, chronic use of benzodiazepines, and family history of hip fracture (3). Additionally, OP development is influenced by the endocrine system, inappropriate lifestyle (e.g. smoking, alcohol abuse, etc.), and use of drugs such as glucocorticoids, 
antipsychotics, and others (4). Patients with diseases such as hyperparathyroidism, thyrotoxicosis, and celiac disease (CD) have increased risk of OP (2). However, few studies have evaluated the prevalence of OP and the clinical risk factors associated with this condition in Latin America, and particularly in Brazil.

$\mathrm{CD}$ is an autoimmune disorder triggered and maintained by the ingestion of gluten from wheat, barley, and rye in genetically predisposed individuals. It has a female preponderance, including women in their fertile period. CD presents a wide variety of clinical manifestations (5). Some patients have the "classical form", in which intestinal symptoms are prevalent. There are "atypical forms" with predominantly extra-intestinal clinical features with dermatological, hematological, endocrinological, reproductive, renal, psychiatric, skeletal, and/or liver involvement; and "silent forms" with no evidence of clinical symptoms $(5,6)$. It affects approximately $1 \%$ of the world population $(5,6)$; in our geographic area, the estimated prevalence is $1 / 475(0.5 \%)(7)$. Nowadays, diagnosis of $\mathrm{CD}$ is based on serologic and histopathological findings. Anti-endomysial (IgA-EmA) and anti-tissue transglutaminase (tTG) antibodies are considered highly specific serological markers; biopsies of the proximal small bowel in positive individuals for these antibodies confirm the diagnosis $(5,6)$. The widespread use of specific serologic tests has increased the prevalence of CD worldwide, including in various Brazilian regions $(7,8)$.

OP prevalence in CD patients is higher than in the whole population $(2,9)$, and may occur even in those with subclinical disease. A metanalysis by Olmos and cols. (4) confirmed a positive association between bone fractures and CD in adult patients. The identification of patients with OP and undiagnosed CD is important because the treatment with a gluten-free diet may help to restore bone mass $(5,10)$. Stenson and cols. found higher prevalence of $\mathrm{CD}$ in patients with osteoporosis compared with controls (3.4 vs. 0.2 , respectively), suggesting that CD should be screened in all osteoporotic patients (11). In this study, we analyzed for the prevalence of silent CD in a population of patients with OP from southern Brazil.

\section{SUBJECTS AND METHODS}

This study has been approved by the local Committee of Ethics in Research, and all participants signed an informed consent form. One hundred consecutive osteoporosis patients of both genders (convenience sample) treated in a single tertiary center were invited to participate. None of them had been diagnosed with CD. Patients with known secondary OP were excluded, including patients with premature gonadal failure, hyperthyroidism, primary hyperparathyroidism, previous glucocorticoid use, use of anticonvulsants and antidepressants, renal failure, inflammatory bowel and rheumatic diseases, known cystic fibrosis, and osteogenesis imperfecta. Demographic, clinical, and X-ray dual-photon absorptiometry (DXA) data were obtained by means of the review of medical charts. OP diagnosis was done when the patients had at least -2.5 standard deviations (SD) below the young-adult mean bone mass density (BMD) or in the T-score of the lumbar spine and/or femoral neck (12).

As a control group, we studied 97 healthy volunteers from the same geographical region matched by age and sex. Five milliliters $(\mathrm{mL})$ of venous blood were collected from each subject. Samples were centrifuged and the serum separated, an aliquot was collected and the sample was immediately stored at $-80^{\circ} \mathrm{C}$ until the tests were performed.

Initial screening of CD was based on the serological determination of IgA anti-endomysial antibodies (IgAEmA), detected by indirect immunofluorescence, with human umbilical cord as substrate and anti-human IgA fluorescent conjugated (INOVA, San Diego, USA). All samples were initially diluted to $1: 2.5$. Determination of IgG anti-tissue transglutaminase (IgG anti-tTG) was done by ELISA (Orgentec ${ }^{\circledast}$, Germany). The cut-off point was of $10 \mathrm{U} / \mathrm{mL}$, in accordance with manufacturer's instructions. All patients with positive serological tests were invited to undergo an upper gastrointestinal endoscopy with duodenal biopsy. Duodenal biopsies, 5 to 7 fragments, were obtained by upper gastrointestinal endoscopy. These specimens, stained by hematoxylineosin, were analyzed for the degree of villous atrophy.

Data were analyzed by frequency tables. Central tendencies were expressed as means \pm SD for parametric data, and as medians and interquartile ranges (IQR) for non-parametric data. Association studies for numerical (non-parametric) data were carried out with Mann-Whitney's test, and for nominal data, with the chi-square test. Statistical analyses were performed with the software Graph Pad prism version 4.0. P-value of 0.05 was considered significant.

\section{RESULTS}

Data on demographic characteristics of osteoporotic patients and matched controls is presented in table 1 . 
Table 1. Data on sample distribution and matched controls (100 osteoporotic patients and 97 controls)

\begin{tabular}{|c|c|c|c|}
\hline & $\begin{array}{l}\text { Patients } \\
\mathrm{N}=100\end{array}$ & $\begin{array}{c}\begin{array}{c}\text { Controls } \\
\mathrm{N}=97\end{array}\end{array}$ & $\mathbf{p}$ \\
\hline Median age (years) & 65 (IQR of $62.0-75.0)$ & $66,0$ (IQR of $62.0-72.0)$ & $0.94\left(^{*}\right)$ \\
\hline Gender (female/male) & $95 / 5$ & $97 / 11$ & $0.10^{(*)}$ \\
\hline Ethnic background & $\begin{array}{c}\text { Caucasian-74/100 (74\%) } \\
\text { Afro-Brazilian-35/100 (35\%) } \\
\text { Asian-1/100 (1\%) }\end{array}$ & $\begin{array}{c}\text { Caucasian-73/97 (75.2\%) } \\
\text { Afro-Brazilian-23/97 (23.7\%) } \\
\text { Asian-1/97 (1.03\%) }\end{array}$ & $0.43^{(* *)}$ \\
\hline Tobacco exposure & $38 / 100$ & $47 / 97$ & $0.13^{(* *)}$ \\
\hline
\end{tabular}

(*) Mann-Whitney test; $\left(^{\star \star}\right)$ Chi-square test.

Mean BMD in the spine was $0.757 \pm 0.107 \mathrm{~g} / \mathrm{cm}^{2}$; in the femur, it was $0.712 \pm 0.101 \mathrm{~g} / \mathrm{cm}^{2}$; mean $\mathrm{T}$ score in the spine was $-2.51 \pm 0.85$, and in the femur, it was $-2.50 \pm 0.43$. There were 53 low impact fractures in 40 patients (18/53 had vertebral fractures; 14/53 had fractures in the forearm; $9 / 53$ in the femur; $4 / 53$ in the humerus; $3 / 53$ in the ankle; $3 / 53$ in the ribs; $2 / 53$ in the clavicle).

In this sample, two patients had a positive IgG-antitTG test (values $13 \mathrm{U} / \mathrm{mL}$ and $10 \mathrm{U} / \mathrm{mL}$ ), and the first one had also a positive anti-EmA IgA (titer 1/5). Both underwent gastrointestinal endoscopy with small bowel biopsy. Just one of them (the one with two positive antibodies) had mucosal alterations that suggested CD (partial atrophy). Upon re-evaluation, this patient (female, 55 years old) was diagnosed with celiac disease, and referred to minor gastrointestinal complaints, such as bloating and abdominal colic pains. She had a $\mathrm{T}$ score of -3.5 , and BMD of $0.666 \mathrm{~g} / \mathrm{cm}^{2}$ in the lumbar spine, and a T score of -2.1 , and BMD of $0.683 \mathrm{~g} / \mathrm{cm}^{2}$ in total femur.

She was followed up by the gastroenterology service, which recommended a gluten-free diet. The other IgG anti-tTG positive patient had a normal duodenal biopsy.

None of controls were positive for either auto-antibodies.

\section{DISCUSSION}

CD is a disease of difficult diagnosis because most of the patients are asymptomatic or present minor symptoms $(5,6)$. Some authors described that half of the adult CD patients are diagnosed after 50 years of age, and population-based studies suggest that $50-90 \%$ of people with CD remain undiagnosed $(6,13)$.

Metabolic bone disease in patients with CD is common and multifactorial $(2,4,9)$. Calcium and vitamin D malabsorption with secondary rise in PTH is one of the causes (14). Increased of pro-inflammatory cytokines, such as interleukin (IL)-1, IL-6, and TNF (tumoral necrosis factor)- $\alpha$ are other contributors. These two first cytokines have been found to be high in both intestinal mucosa and serum of CD patients (15), and serum levels of IL-6 have been found to correlate with lumbar bone mass density (15). Increased ratio of receptor activator of nuclear factor Kappa B ligand (also known as RANK-L)/osteoprotegerin is detected in CD (16). They elevate bone reabsorption due to amplified osteoclast activation and survival (16). Also, clinical and subclinical hypogonadism have been found in CD patients of both genders (17).

While most authors agree that bone health is a problem in $C D$, and that there is an increased rate of fragility fracture in this group of patients $(4,10)$, there is not a clear recommendation as to which OP patients should be screened for CD. Mather and cols. (18) found positive IgA-EmA in $7.3 \%$ of 96 asymptomatic subjects with low BMD, but all positive patients had normal duodenal biopsies. Besides, at least two other studies could not find increased prevalence of CD in an unselected group of women with reduced BMD $(13,19)$. On the other hand, Stenson and cols. (11) showed a higher prevalence of celiac disease in osteoporotic patients from USA compared with controls (3.4\% vs. $0.2 \%)$. Part of these differences may be explained by the influence of the genetic background of the studied population. CD is a disease associated with HLA-DQ2, which appears in over $95 \%$ of patients (10).

Intestinal biopsy is the gold standard test for CD diagnosis (5), but it is invasive and costly; serological screening is the first step in the algorithm for the diagnosis of CD. Serum IgA-EmA and anti-tTG antibody testing have the highest diagnostic accuracy (5). IgAEmA testing is sensitive and highly specific for untreated celiac disease; the sensitivity and specificity of anti-tTG antibodies is 95 and 94 percent, respectively $(5,20)$. As 
it is known, deficiency of $\operatorname{IgA}$ is more frequent in celiac patients, so we also chose to use the anti-tTG class IgG because, if a patient was IgA deficient, then we would prevent the screening of false negatives (20).

At present, we found a very low rate of patients with $\mathrm{CD}$ in $\mathrm{OP}$ patients ( $1 \%)$, probably due to low prevalence of this disease in our geographical area. Based on the costs and benefits, we do not advise CD screening for all OP patients in our region.

Fundings: none.

Disclosure: no potential conflict of interest relevant to this article was reported.

\section{REFERENCES}

1. Johnell O, Kanis J. Epidemiology of osteoporotic fractures. Osteoporos Int. 2005;16(Suppl 2):S3-7.

2. Stazi AV, Trecca A, Trinti B. Osteoporosis in celiac disease and in endocrine and reproductive disorders. World J Gastroenterol. 2008; 14(40):498-505.

3. Pinheiro MM, Ciconelli RM, Martini LA, Ferraz MB. Clinical risk factors for osteoporotic fractures in Brazilian women and men: the Brazilian Osteoporosis Study (BRAZOS). Osteoporos Int. 2009;20:399-408.

4. Olmos M, Antelo M, Vazquez H, Smecuol E, Mauriño E, Bai JC. Systematic review and meta-analysis of observational studies on the prevalence of fractures in coeliac disease. Dig Liver Dis. 2008;40:46-53.

5. Rubio-Tapia A, Hill ID, Kelly CP, Calderwood AH, Murray JA. ACG clinical guidelines: diagnosis and management of celiac disease. Am J Gastroenterol. 2013;108(5):656-76.

6. Kotze LMS. Celiac disease in Brazilian patients: associations, complications and causes of death. Forty years of clinical experience. Arq Gastroenterol. 2009;46(4):261-9.

7. Pereira MA, Ortiz-Agostinho CL, Nishitokukado I, Sato MN, Damião AO, Alencar ML, et al. Prevalence of celiac disease in an urban area of Brazil with predominantly European ancestry. World J Gastroenterol. 2006;12:6546-50.
8. Melo SB, Fernandes MI, Peres LC, Troncon LE, Galvão LC. Prevalence and demografic characteristics of celiac disease among blood donors in Ribeirão Preto, State of São Paulo, Brasil. Dig Dis Sci. 2006;51:1020-5.

9. Stazi AV, Trinti B. Risk of osteoporosis in endocrine disorders and celiac disease. Ann Ist Super Sanità. 2007;43:430-3.

10. Bianchi M-L, Bardella MT. Bone in celiac disease. Osteoporos Int. 2008;19:1705-16.

11. Stenson WF, Newbwrry R, Lorenz R, Baldus C, Civitelli R. Increased prevalence of celiac disease and need for routine screening among patients with osteoporosis. Arch Intern Med. 2005;165:393-9.

12. World Health Organization. Assessment of fracture risk and its application to screening for postmenopausal osteoporosis. Geneva 1994. Available at: http://whqlibdoc.who.int/trs/WHO_TRS_843. pdf. Accessed on: Mar 9, 2013.

13. Drummond FJ, Annis P, O'Sullivan K, Wynne F, Daly M, Shanahan $F$, et al. Screening for asymptomatic celiac disease among patients referred for bone densitometry measurement. Bone. 2003;33:970-4.

14. Capriles VD, Martini LA, Arêas JA. Metabolic osteopathy in celiac disease: importance of a gluten-free diet. Nutr Rev. 2009;67:599606.

15. Larussa T, Nazionale ESI, Abenavoli L, Imeneo M, Luzza F. Bone mineralization in celiac disease. Gastroenterol Res Pract. 2012;198025.

16. Taranta A, Fortunati $D$, Longo $M$, Rucci $N$, lacomino $E$, Alberti $F$, et al. Imbalance of osteoclastogenesis regulating factors in patients with celiac disease. J Bone Miner Res. 2004;19:1112-21.

17. Stazi AV, Antonello Trecca A, Trinti B. Osteoporosis in celiac disease and in endocrine and reproductive disorders. World J Gastroenterol. 2008;14:498-505.

18. Mather KJ, Meddings JB, Beck PL, Scott RB, Hanley DA. Prevalence of IgA-antiendomysial antibody in asymptomatic low bone mineral density. Am J Gastroenterol. 2001;96:120-5.

19. O'Leary C, Feighery C, Feighery A, Quane K, Shanahan F, Molloy $\mathrm{M}$, et al.The prevalence of coeliac disease among female subjects having bone densitometry. Ir J Med Sci. 2002;171:145-7.

20. Rostami Nejad M, Rostami K, Pourhoseingholi MA, Nazemalhosseini Mojarad E, Habibi M, Dabiri $H$, et al. Atypical presentation is dominant and typical for coeliac disease. J Gastrointestin Liver Dis. 2009;8:285-91. 